\title{
CONTRIBUTION OF MICROMORPHOLOGY TO THE TAXONOMY OF ABRUS (LEGUMINOSAE-PAPILIONOIDEAE)
}

\author{
G. TEIXEIRA ${ }^{1} \&$ M. ADÉLIA DINIZ ${ }^{2}$
}

\begin{abstract}
SUMMARY
Despite the various taxonomic revisions of Abrus Adans., species and infraspecific delimitation are not always clear. In those revisions very little reference is made to micromorphological characters, in particular to those of the compound leaves, in spite of the stability of some of those characters. By using techniques of light and scanning microscopy this study reveals some interesting results concerning to leaflet surface, such as some of the characters of the epidermis cells, stomata, presence of papillae and trichomes. These characters show some range of variation at the species level but not at the subspecies level.

We conclude that those structures can provide additional characters useful in Abrus for species and infraspecific segregation. This study also supports Breteler's delimitation of the African Abrus species.
\end{abstract}

Key words: Abrus, Papilionoideae, leaflet, microcharacters, taxonomy.

\section{INTRODUCTION}

Abrus Adans. is a small natural genus of the Leguminosae family, subfamily Papilionoideae, originated from South Asia (Breteler, 1960; Verdcourt, 1971) and nowadays distributed through tropical and subtropical areas (Kerharo, 1974; Iwu, 1993). Its taxonomy presents some difficulties beginning with a controversial delimitation of species and infraspecific taxa (Breteler, 1960; Verdcourt, 1971; Lebrun \& Stork, 1992). In previous taxonomic studies of Abrus, authors only considered the gross morphology from floral and also from some vegetative structures and little micromorphological information was considered.

Adanson (1763) first described the genus, but he made no combination for the species intended as a base for the genus. Breteler (1960) distinguishes in Africa four species: Abrus fruticulosus Wall. ex Wight \& Arn., A. precatorius L., A. canescens Welw. ex Baker and A.diversifoliolatus Breteler, using leaflet, inflorescence, bract, pod and seed characteristics. A decade later, Verdcourt (1971) returned to the existence of seventeen species and several subspecies on the basis of flower characteristics, seed colour and form and leaf indumentum. This multitude is mainly caused by the complex of A. fruticulosus. This species and A.precatorius are circumtropical in distribution and both show a considerable morphological plasticity, in particular A. fruticulosus. That

1) Centro de Biologia Ambiental, Faculdade de Farmácia da Universidade de Lisboa, Ava das Forças Armadas, 1649-019 Lisboa, Portugal (e-mail: gteixeira@ff.ul.pt).

2) Centro de Botânica, Instituto de Investigação Científica Tropical, Trav. Conde da Ribeira 9, 1300-142 Lisboa, Portugal (e-mail: cbotn@iict.pt). 
plasticity is always restricted to size, shape and number of leaflets, shape or place of the inflorescence, size or shape of the pods and may be connected with the fact that this species can occupy very different habitats: from rain forest to savannah and even to semi-desert. It is known that some of those characters are very plastic and, facing this, some authors agree that it is not advisable to segregate the forms of a species into a considerable number of different taxa. Breteler (1960) concluded that some of the forms of A.fruticulosus could not be separated and be considered as a distinct taxon.

Phytochemical studies in leaves, roots and seeds of A.precatorius revealed the presence of several triterpenes (Chiang et al., 1983; Choi et al., 1989a, b; Kinghorn et al., 1995). Based on the novel cycloartane type aglycone, abrusogenin, those compounds were identified as abrusosides, sweet tasting triterpene-glycosides, having a much greater edulcorate capacity than saccharose (Iwu, 1993). There are also references about the existence of several common fitosterols in leaves (Maiti, 1970; Bhaumik, 1987; Hutchings et al., 1996) and some more specific steroids in the seeds (Maiti, 1970; Bhaumik, 1987) of other species of the genus Abrus. The presence of indole alkaloids in the leaves of A. precatorius is also mentioned by Kerharo (1974) and Hutchings et al. (1996). Some of these groups of compounds were also detected by histochemical tests on the leaves of A.pulchellus Wall. ex Thwaites (Teixeira et al., in press). We also noticed the presence of phenolic compounds by both histochemical and fluorescence tests. PAS reagent revealed the presence of non-cellulosic polysaccharides.

The genus Abrus is very common in Guinea-Bissau, where three African species are present: A. precatorius, A. canescens and A.pulchellus. In Cape Verde Islands only A. precatorius is found. These species usually present a climbing habit. Their roots, leaves and seeds are used in folk medicine, in spite of its known toxicity, specially, the seeds. They are described as anti-inflammatory, expectorant, antitussive, antimicrobial, and they are also used against general pains as well as a powerful edulcorate (Kerharo, 1974; Choi et al., 1989a, b; Diniz et al., 2000).

In the present work the microcharacters of the leaves of the African Abrus species, with the exception of $A$. diversifoliolatus from Madagascar, were studied using different techniques of light and scanning microscopy. These microcharacters contribute to a better understanding of Abrus taxonomy, and in the identification of fragmented or entire samples of natural plant products of the different Abrus species.

\section{MATERIALS AND METHODS}

\section{Plant material}

Small branches of A.pulchellus were collected from wild populations in Canchungo, North Guinea-Bissau, in 1997. They were pressed and dried for later study. A voucher exemplar (Falcão s.n.) is deposited in IICT Herbarium (LISC), in Lisbon. Herbarium specimens from the same institution were also studied (Table 1). Those specimens are representative of the African Abrus species.

\section{Light microscopy (LM)}

Dried material was previously hydrated in tepid water. Entire leaflets were observed by stereomicroscopy in a Nikon SMZ-2T. Transverse sections were made by hand in the midregion of mature leaflets. After that, entire leaflets and sections were cleared in 
Table 1. Abrus herbarium specimens included in the study.

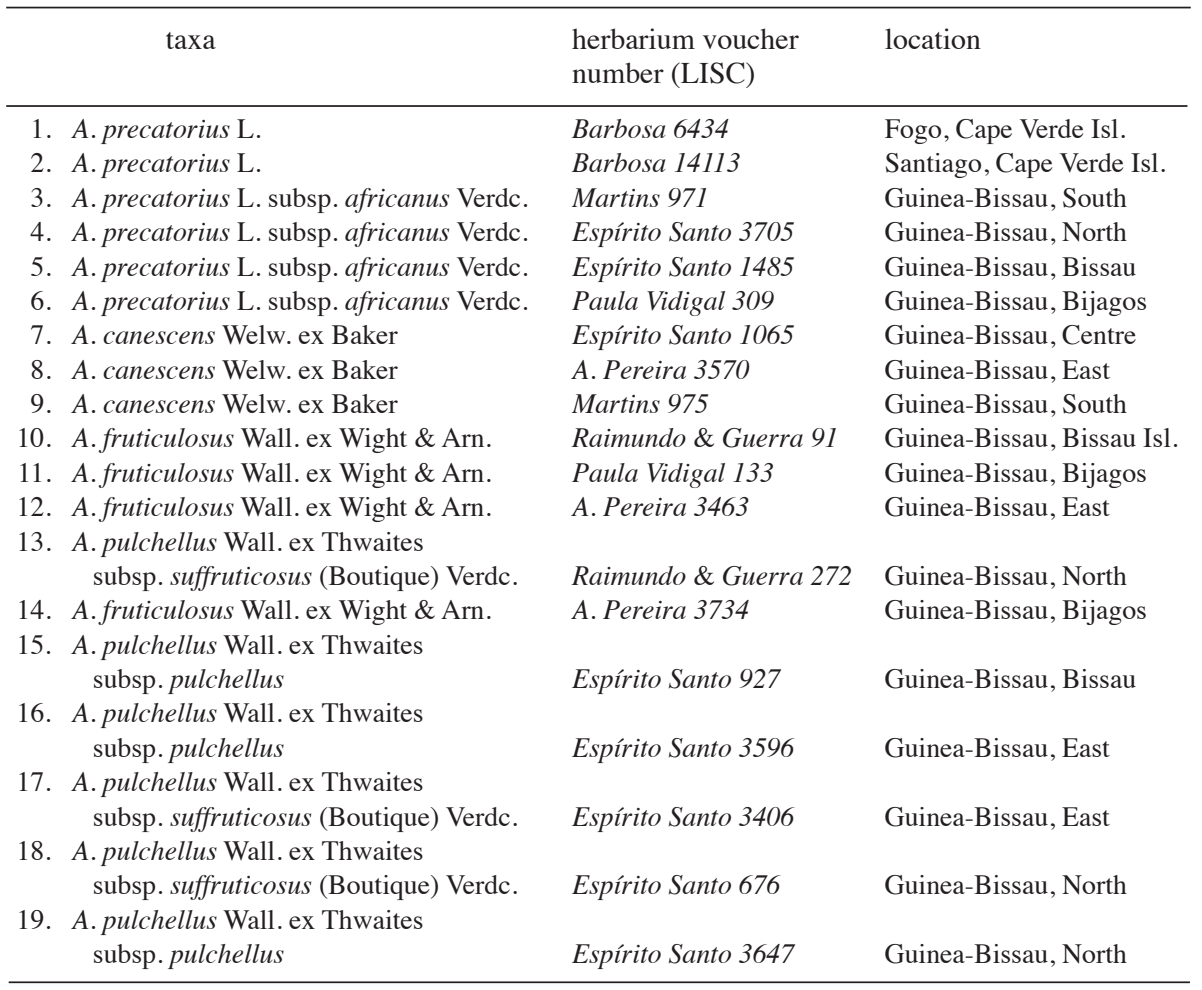

chloral hydrate solution and washed in distilled water (Evans, 1996). Light microscopic observations were carried out on a Nikon Labophot 2 microscope.

The description of morphological characters used in the study is given in Table 2 and Table 3. Qualitative and quantitative characters are the average of ten observations per specimen. Stomata index was observed according to Salisbury (1927). Trichome index was observed on both surfaces following Dilcher (1974).

Scanning Electron Microscopy (SEM)

Samples from dried herbarium specimens were directly mounted on stubs and coated with gold for observation, with a Jeol JSM 5200 LV scanning electron microscope, at $15 \mathrm{KV}$.

\section{RESULTS}

The results are summarized in Table 2 and Table 3 . All the specimens present a similar leaflet shape, varying between ovate oblong in A.precatorius and A.precatorius subsp. africanus Verdc., to elliptic oblong in A. canescens and elliptic in all the other taxa.

The ratio length/width is not constant within each taxon (Table 2) but there is a general tendency: A. canescens presents the biggest length/width ratio and A. preca- 

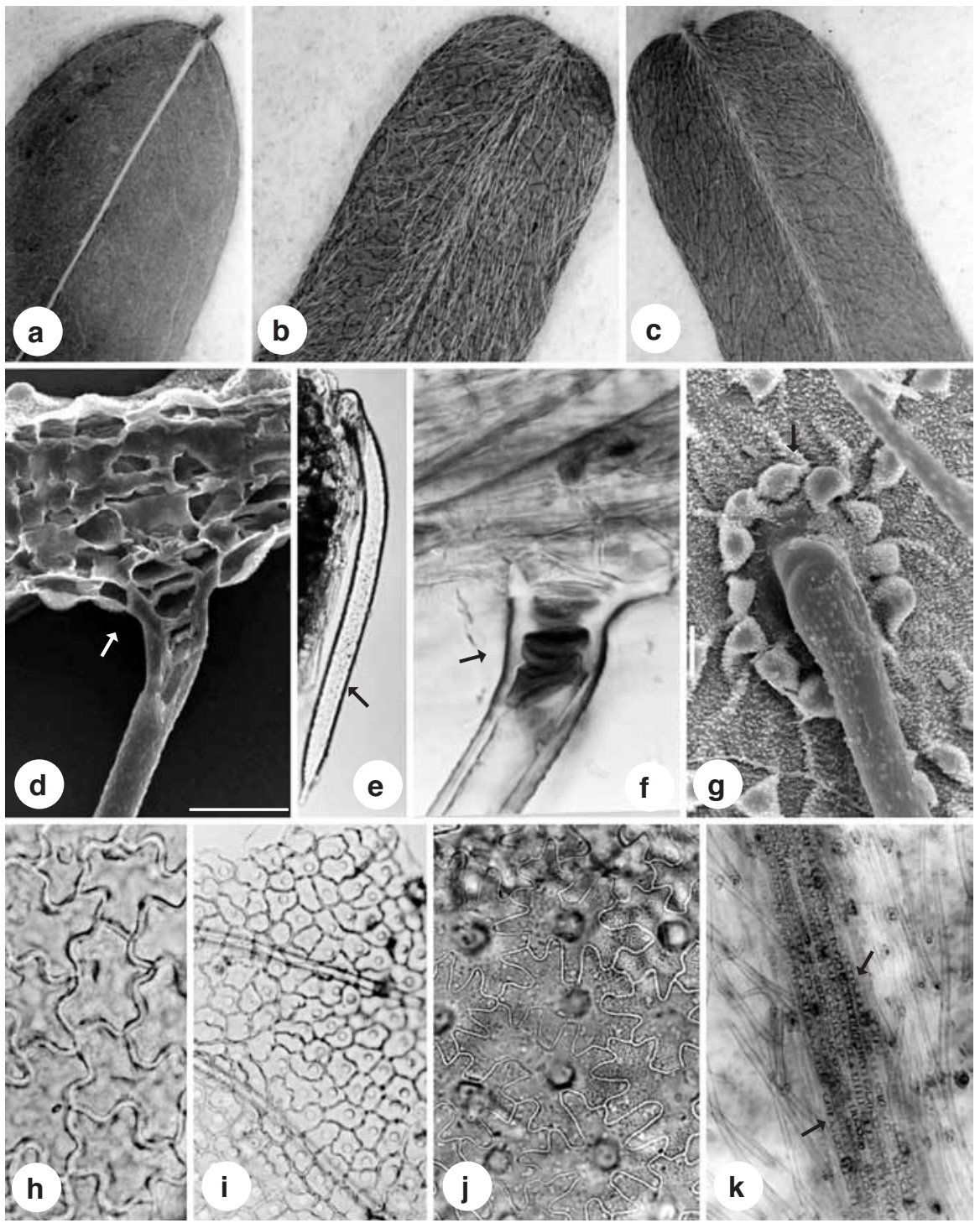

Plate 1. - a. Abrus precatorius L. ovate oblong leaflet: lower surface slightly pubescent $(\times 4)$. b. A. canescens Welw. ex Baker elliptic oblong leaflet: lower surface densely pubescent $(\times 4)$. c. A. fruticulosus Wall. ex Wight \& Arn. elliptic leaflet: lower surface normally pubescent $(\times 4)$. d. A. pulchellus Wall. ex Thwaites multicellular trichome: basal cells (arrow, SEM; scale bar $=50 \mu \mathrm{m}$ ). - e. A.pulchellus subsp. suffruticosus (Boutique) Verdc. multicellular trichome: basal cells followed by a long pointed cell (arrow, $\times 100)$. $-\mathrm{f}$. A. pulchellus Wall. ex Thwaites multicellular trichome: basal cells with an orange-brownish content $(\times 450) .-\mathrm{g}$. A. pulchellus Wall. ex Thwaites subsp. pulchellus leaflet lower surface: trichome surrounded by a ring of papillae (SEM; scale bar $=50 \mu \mathrm{m}$ ). $-\mathrm{h}$. A. precatorius subsp. africanus Verdc. leaflet upper surface: undulated epidermis cells $(\times 425)$. - i. A. canescens Welw. ex Baker leaflet upper surface: straight epidermis cells $(\times 125)$. $-\mathrm{j}$. A. fruticulosus Wall. ex Wight \& Arn. leaflet upper surface: stellate epidermis cells $(\times 125)$. - k. A. canescens Welw. ex Baker leaflet lower surface: styloids (arrows, $\times 125$ ). 
torius subsp. africanus the smallest. All species have an indumentum with a different distribution and a particular trichome index (Table 2, Plate 1a-c). They are tector trichomes present on both surfaces but sometimes they are broken. In A. precatorius and A. precatorius subsp. africanus trichomes are very sparse on the upper surface. Trichomes are randomly distributed, always more dense above the central vein. They are similar in all the taxa, being single, uniseriate, multicellular, showing two, three or four small basal cells (Plate 1d), followed by a long pointed cell always leaning to the apex (Plate 1e). The trichome basal cells have an orange-brown content (Plate 1f) which is characteristic in all the taxa with the exception of A.precatorius and A.precatorius subsp. africanus. The trichomes have a different length, depending on the leaflet surface and on the species (Table 2). Abrus precatorius is the only taxon that does not show papillae on both leaflet epidermal surfaces (Table 3). In A. precatorius subsp. africanus the situation is similar but the lower epidermis is subpapillose. In A.canescens the upper surface is subpapillose and the lower surface is papillose. In $A$. fruticulosus and A.pulchellus, as well as in all their subspecies, both surfaces are clearly papillate. When present, the papillae are random distributed on the two surfaces and each trichome is surrounded by a ring of papillae (Plate $1 \mathrm{~g}$ ).

In A. precatorius and A. precatorius subsp. africanus the epidermal cells are similar on both surfaces and exhibit undulated walls and various dimensions, being slightly longer than wide, arranged without any definite pattern of orientation (Table 3, Plate 1h). The cuticle surface is granular, with a variable thickness, between $2-4.1 \mu \mathrm{m}$.

In A. canescens the epidermal cells have different characteristics on the two surfaces. On the upper surface the cells with straight walls are somewhat polygonal, sometimes isodiametric or slightly elongated and randomly oriented (Plate 1i). On the lower surface the cell walls are considerably more undulate but still polygonal, sometimes elongated and without any orientation. The cuticle surface is granular and about $3 \mu \mathrm{m}$ thick.

In the remaining species and subspecies the epidermal cells are stellate on both surfaces (Plate 1j). The cuticle surface and thickness are similar to those in A. canescens.

In all species the stomata are hypostomatal, superficial and without any pattern of orientation or distribution. They are subcircular in A. canescens, $17 \mu \mathrm{m}$ long and 13-14 $\mu \mathrm{m}$ wide. In A. precatorius the stomata are broadly elliptic, 20-22 $\mu \mathrm{m}$ long and $12 \mu \mathrm{m}$ wide. In all the other taxa they are elliptic, ranging 17-22 $\mu \mathrm{m}$ long and 10-15 $\mu \mathrm{m}$ wide. The stomatal index ranges from 6.6 in A. precatorius subsp. africanus to 13.1 in A canescens.

In A.precatorius and A. precatorius subsp.africanus the subsidiary cells are paracytic although a few anomocytic can be seen. In all the other species, anisocytic and paracytic types are intermixed, presenting no definite pattern of orientation and distribution.

Styloid-like crystals are found, usually near the veins, immediately below the vascular tissues. In A. canescens they seem to be numerous (Plate 1k) but in A.precatorius and in A. precatorius subsp. africanus they seem less abundant (Table 3 ).

In all the specimens the mesophyll is bifacial and exhibits 1 or 2 layers of palisade cells. The veins are abaxially prominent and a bundle sheath of sclerenchyma surrounds them. In the central vein the vascular tissues are subdivided into 3-5 bundles and the shape of the bundle sheath varies with species: it is circular in A.fruticulosus, broadly elliptical in A.precatorius subsp. africanus and elliptical in the other species. 


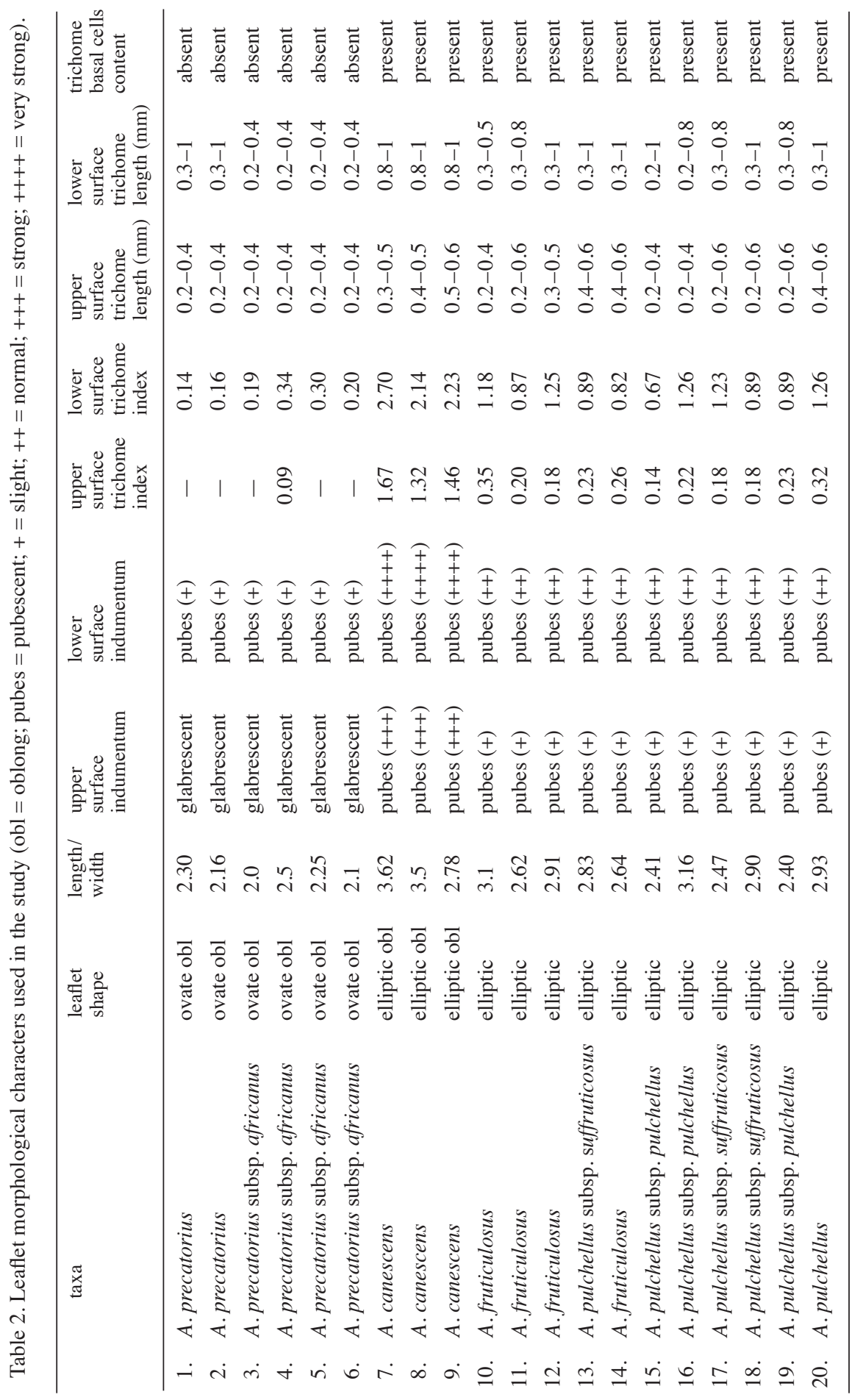




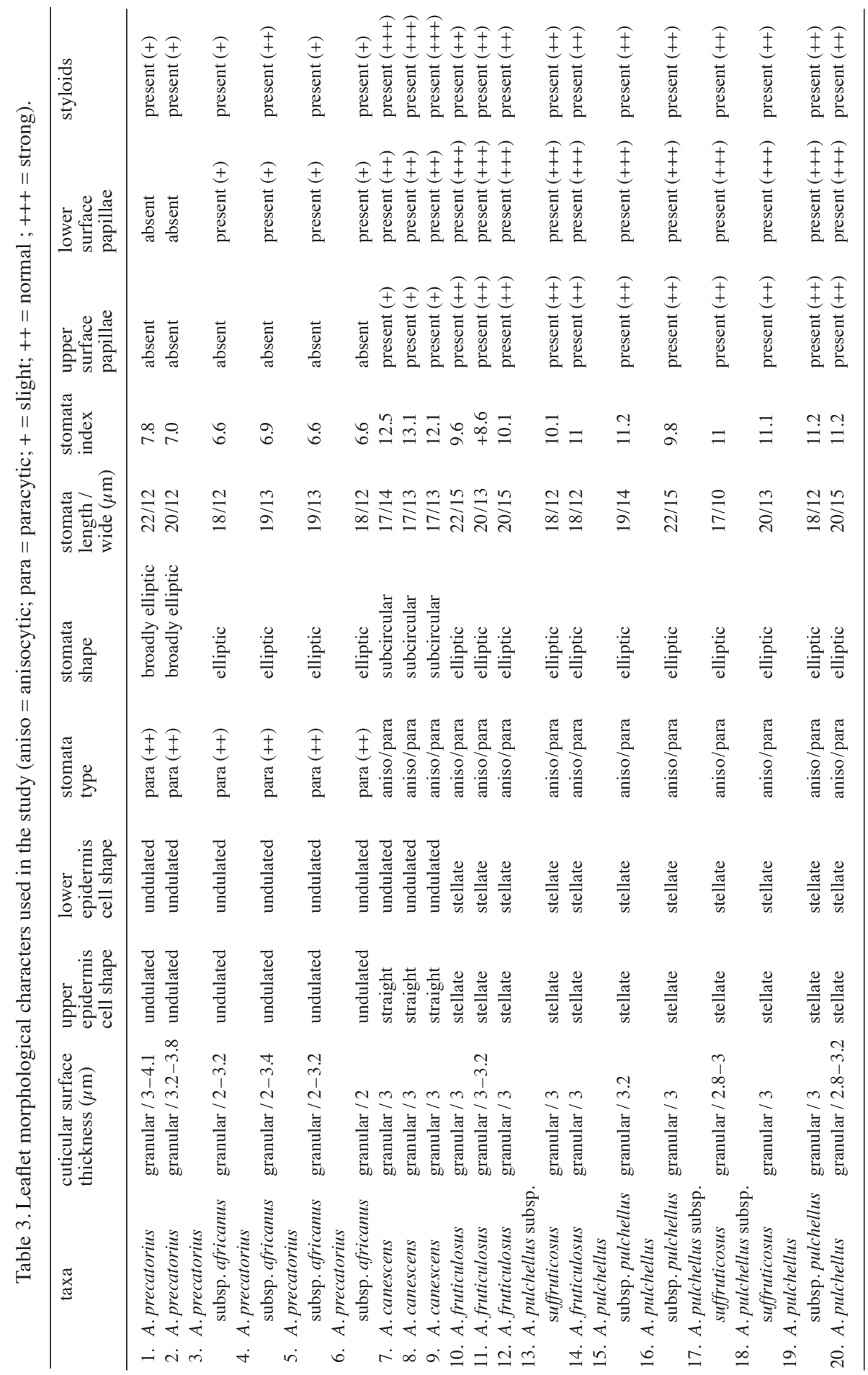




\section{DISCUSSION}

The microscopic features of the epidermis are of great importance in taxonomic studies and are still very incompletely known in many botanical groups. Their use as a complement to macrocharacters for taxonomical purposes is highly advisable especially in genera where hybridization obscures the specific or infraspecific limits.

The herbarium material used for this study proved to be suitable for epidermal studies but was poor for the detailed anatomical observations. Despite that, the transverse sections of the leaflets lamina seem to be uniform within and between taxa, and so have limited taxonomic value, and were not considered in this study.

Analysing Table 1 we can see that the individuals studied have different origins and lived in different habitats. In consequence it is acceptable that they show several adaptations in their morphology, anatomy and physiology. In spite of that, the microcharacters considered, in particular, the leaf indumentum, the epidermal cell shape of the upper and lower surfaces, the stomata type and the presence of papillae, show some range of variation between species but not at the subspecific level (Table 2,3).

It is generally accepted that the variability of leaf colour, size and shape has a very limited taxonomic value. We gave special attention to the ratio between length/width, which is thought to be more reliable than just leaflet size. We noticed that A.canescens has the largest ratio between length and width, being the narrowest leaflets, and A.precatorius subsp. africanus the smallest ratio, being the wider leaflets. The observation of the leaflet shape in all the specimens is somehow difficult because of their similarity. Nevertheless we consider slight differences (Table 2).

In the subfamily Papilionoideae papillose upper epidermis is only recorded in species of Dalbergia and Spartium (Metcalfe \& Chalk, 1950). The same authors also mentioned that in species of Abrus the lower epidermis is papillose or subpapillose. We observed that this situation is not completely true: only the lower epidermis of $A$. precatorius subsp. africanus is subpapillose; A. precatorius does not have papillae on both faces and all the other taxa do have papillae on both leaflet surfaces, with a different spacing and a different dimension.

We did not notice any considerable differences on the granular cuticle surface (Table 3 ). The differences on thickness are attributed to different environmental conditions of plant material and so it is not a reliable character.

The characteristics of the leaf indumentum, such as the length of the trichomes and their index, although also affected by environmental factors, are almost constant within each taxon, denouncing the existence of three groups: A. precatorius and $A$. precatorius subsp. africanus, A. canescens and A.fruticulosus and A.pulchellus and all their subspecies.

In A. canescens the trichomes are longer and the indumentum is denser on both surfaces when compared with the other species, but the differences of the cuticle thickness and the position of the stomata between this and the other taxa are not significant.

Besides the usual characteristics of the trichomes, which may be very useful in taxonomy, in Abrus we may also consider as a distinguishing character the presence or absence of an orange-brown substance in the basal cells. In A.precatorius and A.precatorius subsp. africanus that coloured content is not seen, unlike what happens on all the other taxa. In A. pulchellus that content consists of lipophilic as well as of phenolic compounds (Teixeira et al., 2002). 
Characters such as the epidermis cells shape and type and shape of the stomata, are not plastic characters and are of considerable taxonomic value (Metcalfe \& Chalk, 1950; Stace, 1980). These characters also show some range of variation between species but not at the subspecific level (Table 3). Stace (1965) considers that when stomata dimension is constant within one taxon it may be considered a reliable character. We believe this is the situation.

The stomata density is of restricted value because it is environmentally influenced (Metcalfe \& Chalk, 1950). Some authors prefer the stomata index which, according to Rowson (1946), is independent from the habitat, from the age of the plant and from the leaf surface position from where it is studied.

Calcium oxalate crystals of styloid type are recorded in all the taxa examined. They seem to be more frequent in A. canescens. Usually styloids vary considerable in size and shape and this variation has some taxonomic application among some species, particularly in monocotyledons (Wu \& Cutler, 1985). Styloids are usually found in mesophyll tissues, in parenchymatous bundle sheath cells around vascular strands or even in epidermal cells. In all the studied specimens they appear more or less cubical, usually solitary within the cells of the parenchymatous bundle sheath around the veins. This is possible probably due to calcium transport through the xylem. Calcium oxalate crystals can appear in a variety of shapes which are consistent and repeatable from one generation to the next, demonstrating that the physiological and genetic parameters controlling them are consistent (Prychid \& Rudall, 1999).

Phytochemical studies of some of this species, A.precatorius and A.pulchellus, are ongoing in the Faculty of Pharmacy of the University of Lisbon (Falcão, pers. comm.) and some of the detected compounds, namely flavonoids and terpenoids, might be useful as taxonomic markers.

Some epidermal micromorphological characters, such as the characters related with epidermis cells, stomata, presence of papillae and trichome, can provide additional characters of taxonomic value to distinguish Abrus species.

Analysing Table 2 and 3 we can clearly see the existence of three groups: i) A.precatorius and A. precatorius subsp. africanus; ii) A. canescens and iii) A. fruticulosus and A. pulchellus and their subspecies. Inside each of these groups there is a great homogeneity of characters what refutes any further speciation.

In conclusion, there are some small differences inside the first group which justifies the existence of A. precatorius subsp. africanus. But there appears to be no definite reason to establish any distinction between A.fruticulosus and A.pulchellus or considering the infraspecific levels A. pulchellus subsp. suffruticosus and A. pulchellus subsp. pulchellus. According to Thwaites' description (1859) and to the studies of Breteler (1960) A. pulchellus is conspecific with A.fruticulosus. So this study supports Breteler's opinion that it is not advisable to segregate the different forms of A. fruticulosus and considering them as distinct taxa.

\section{ACKNOWLEDGEMENTS}

The authors are grateful to J. Falcão for some plant material supply. Thanks are also due to Dr. T. Nunes of Centro de Biologia Ambiental, Faculty of Sciences of the University of Lisbon, for his technical assistance. 


\section{REFERENCES}

Adanson, M. 1763. Familles des Plantes 2: 327. Vincent, Paris.

Bhaumik, H. 1987. Hydrocarbons, fatty acids, triterpenoids and sterols in the seeds of Abrus precatorius L. Science Culture 53: 23-24.

Breteler, F.J. 1960. Revision of Abrus Adanson (Pap.) with special reference to Africa. Blumea 10: 607-624.

Chiang, T.-C.,H-M. Chang \& T. Mak. 1983. New oleanene type triterpene from Abrus precatorius and X-ray crystal structure of abrusgenic acid methanol 1:1 solvate. Planta Medica 49: 165-169.

Choi, Y-H., R. Hussain, J. Pezzuto, D. Kinghorn \& J. Morton. 1989a. Abrusosides A-D, four novel sweet-tasting triterpene glycosides from leaves of A. precatorius L. J. Nat. Prod. 52: $1118-1127$.

Choi, Y-H., D. Kinghorn, X. Shi, H. Zhang \& B. Teo. 1989b. Abrusoside A: a new type of highly sweet triterpene glycoside. J. Chem. Soc. - Chem. Comm. 13: 881.

Dilcher, D. 1974. Approaches to the identifications of angiosperm leaf remains. Bot. Rev. 40: $1-157$.

Diniz, M.A., E.S. Martins, E. Gomes \& O. Silva. 2000. Contribuição para o conhecimento de plantas medicinais da Guiné-Bissau. V Jornadas de Taxonomia Botânica, 16-19 Setembro de 1999, Lisboa. Portugaliae Acta Biologica 19: 417-427.

Evans, W.C. 1996. Trease and Evans Pharmacognosy. 14th ed. Saunders Company Ltd, London.

Hutchings, A., A. Scott, G. Lewis \& A. Cunningham. 1996. Zulu medicinal plants. University Natal Press, Pietermaritzburg.

Iwu, M. 1993. Pharmacognostical profile of selected medicinal plants. In: Handbook of African Medicinal Plants. CRC Press, Boca Raton.

Kerharo, J. 1974. Plantes medicinales et toxiques. In: La Pharmacopée Sénégalaise Traditionelle. Vigot Frères, Paris.

Kinghorn, D., R. Suttisri \& I-S. Lee. 1995. Search for noncariogenic sweeteners from medicinal plants. In: Phytochemistry of plants used in traditional medicine: 165-188.

Lebrun, J.-P. \& A.L. Stork. 1992. Enumération des plantes à fleures d'Afrique Tropicale 2: 60.

Maiti, L. 1970. Chemical examination of seeds of Abrus precatorius L. J. Indian Acad. Forensic Sci. 9: 64-68.

Metcalfe, C. \& L. Chalk. 1950. Anatomy of dicotyledons. Clarendon Press, Oxford.

Prychid, C. \& P. Rudall. 1999. Calcium oxalate crystals in monocotyledons: a review of their structure and systematics. Ann. Bot. 84: 725-739.

Rowson, J. 1946. The significance of the stomatal index as a differential character. III. Studies on the genera Atropa, Datura, Digitalis, Phytolacca and in polyploid leaves. Quart. J. Pharm. Pharmacol. 19: 136-143.

Salisbury, E. 1927. On the causes and ecological of stomatal frequency with special reference to the woodland flora. Philos. Trans. R. Soc. B. 216: 1-65.

Stace, C. 1965. Cuticular studies as an aid to plant taxonomy. Bull. British Museum (Natural History) - Botany 4: 1-78.

Stace, C. 1980. Plant taxonomy and biosystematics. Arnold, London.

Teixeira, G., J. Falcão \& M.A Diniz. In press. Morphological and histochemical studies on Abrus pulchellus leaves. Rev. Ciências Agrárias.

Thwaites, G. 1859. Enumeratio plantarum zeilaniae: 91. Dulan \& Co., London.

Verdcourt, B. 1971.Abreae. In: E. Milne-Redhead \& R.M. Polhill (eds.), Flora of Tropical East Africa, Leguminosae subfam. Papilionoideae, 3: 113-118, Crown Agents, London.

Wu, Q-G. \& D.F. Cutler. 1985. Taxonomic evaluation and ecological implications of the leaf anatomy of rhizomatous Iris species. Bot. J. Linn. Soc. 90: 253-303. 